\title{
CONSILIUM
}

Berkala Kajian Konseling Dan Ilmu Keagamaan

Avalaible at http://jurnal.uinsu.ac.id/index.php/consilium

ISSN : 2338-0608 (Print) | ISSN : 2654-878X (Online)

\section{HUKUM MENIKAH DINI DAN DAMPAKNYA BAGI PENDIDIKAN ANAK}

\begin{abstract}
Ali Akbar*
Fakultas Dakwah dan Komunikasi, Universitas Islam Negeri Sumatera Utara Medan.

*Korespondensi: aliakbar@uinsu.ac.id
\end{abstract}

\begin{abstract}
Ideally a person who is going to get married should have grown up both physically and thoughtfully for the sake of the realization of a harmonious, happy and prosperous couple, but many factors that cause early marriage include caused by excessive courtship and eventually pregnancy out of the wedlock or because of dependents his/her parents were too much so that their underage children were forced to mate to reduce their parents' costs because there were still many siblings, or because their lives were so difficult that an underage child was married by his parents or the child was married to someone older but his life is well established so that it is expected from the marriage that it can help the economy of the family of the father and mother. The household is the first place for children to develop mental and personality formation which is than refined informal and non-formal education. Likewise the case with religious education must be started in the household as early as possible, such as the practice of prayer, fasting and others. Creating a religious atmosphere in the household not only makes the members of the household happy but also has a great influence on the formation of a religious human personality for the children.
\end{abstract}

Keywords: Early marriage, impact, and Children's education.

\section{PENDAHULUAN}

7 iap manusia memiliki hasrat dan keinginan dalam dirinya untuk hidup berkelompok dan berdampingan dengan orang lain, hal tersebut diwujudkan dengan melaksanakan perkawinan antara seorang pria dan seorang wanita. Dasar hukum tentang perkawinan dalam hukum Islam telah diatur di dalam Alquran dan al-Hadis, antara lain :

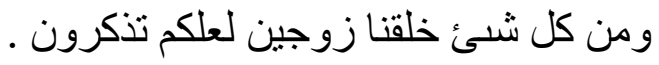

Artinya : Dan segala sesuatu kami ciptakan berpasang-pasangan supaya kamu mengingat akan kebesaran Allah. (QS. al-Dzariyat ayat 49) (Departemen Agama Republik Indonesia, 1989). 


$$
\begin{aligned}
& \text { ياأيها الناس اتقو ا ربكم الذى خلقكم من نفس واحدة وخلق منها زوجها وبث منها رجالا كثير اونسآء } \\
& \text { ( النساء: ( } 1 \text { ( الناس }
\end{aligned}
$$

Artinya : Hai sekalian manusia, bertakwalah kepada Tuhanmu yang telah menciptakan kamu dari seorang diri, dan dari padanya Allah menciptakan istrinya, dan dari keduanya Allah mengembangbiakkan laki-laki dan perempuan yang banyak... (QS. An-Nisa` : 1) (Departemen Agama Republik Indonesia, 1989).

$$
\text { سبحان الذى خلق الأزو اج كلها مما تنبت الأرض ومن أنفسهم ومما لايعلمون ( يس : } 36 \text { ). }
$$

Artinya : Maha suci Allah yang telah menciptakan pasangan-pasangan semuanya, baik apa yang ditumbuhkan dari bumi dan dari diri mereka maupun apa yang tidak mereka ketahui .(QS. Yaasiin : 36) (Departemen Agama Republik Indonesia, 1989).

Dari makhluk yang diciptakan oleh Allah Swt. berpasang-pasangan inilah Allah Swt. menciptakan manusia menjadi berkembang biak dan berlangsung dari generasi ke generasi berikutnya. Salah satu hadis Rasulullah yang juga menganjurkan manusia, khususnya umat muslim untuk melaksanakan perkawinan, yaitu :

$$
\text { ... و أتزوج النسآء فمن رغب عن سنتى فليس منى (رو اه الجماعة و المسلم ). }
$$

Artinya : ... Dan Aku mengawini wanita-wanita, barangsiapa yang benci terhadap sunnahku, maka ia bukan termasuk ummatku.

Pernikahan dini merupakan fenomena sosial yang banyak terjadi di berbagai wilayah. Fenomena pernikahan dini bagai fenomena gunung es yang hanya tampak sebagian kecil di permukaan, sangat sedikit terekspos di ranah publik, tetapi kenyataannya begitu banyak terjadi di kalangan masyarakat luas. Orang tua yang berpengalaman dan berpendidikan akan lebih baik dalam memberikan pendidikan kepada anak-anakya dalam keluarga. Dapatkah ibu yang masih kekanak-kanakan memelihara, mendidik dan membimbing anaknya dengan sempurna?

\section{KAJIAN TEORETIS}

\section{Pengertian Pernikahan}

Pernikahan, berasal dari kata nikah ( نكاح ) yang menurut bahasa artinya mengumpulkan, saling memasukkan, dan digunakan untuk arti bersetubuh (wathi) (al-Jurjaniy, 1988; Al-Kahlaniy, n.d.). Kata nikah sendiri sering digunakan untuk arti persetubuhan (coitus), juga untuk arti akad nikah (Al-Zuhaili, 1989). Pernikahan disebut juga perkawinan, perkawinan berasal dari kata kawin yang 
menurut bahasa artinya membentuk keluarga dengan lawan jenis, melakukan hubungan kelamin atau bersetubuh (Depdikbud, 1994).

Menurut istilah hukum Islam, terdapat beberapa definisi, di antaranya adalah:

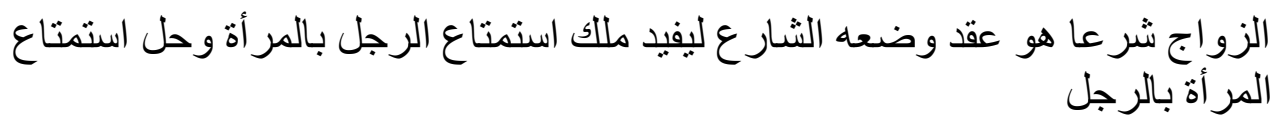

Artinya : Perkawinan menurut syara`yaitu akad yang ditetapkan syara` untuk membolehkan bersenang-senang antara laki-laki dengan perempuan dan menghalalkan bersenang-senangnya perempuan dengan laki-laki (Al-Zuhaili, 1989).

Abu Yahya Zakariya al-Anshary mendefinisikan :

$$
\text { النكاح شر عا هو عقد يتضمن اباحة وطئ بلفظ انكاح أونحوه . }
$$

Artinya : Nikah menurut istilah syara' ialah akad yang mengandung ketentuan hukum kebolehan hubungan seksual dengan lafaz nikah atau dengan kata-kata yang semakna dengannya.

Substansi hukum Islam adalah menciptakan kemaslahatan sosial bagi manusia baik di masa sekarang maupun di masa yang akan datang. Hukum Islam bersifat luas dan luwes, humanis dan selalu membawa rahmat bagi seluruh manusia di alam ini (As-Syathibi, n.d.).

Pada mulanya hukum menikah adalah sunnah sesuai dengan Alquran surat an-Nisa` ayat 3 :

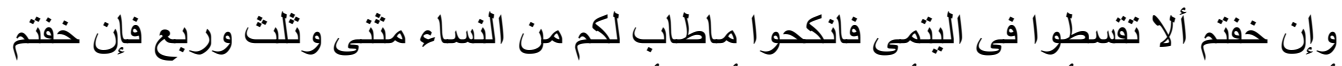

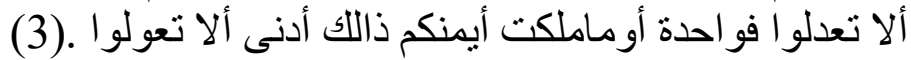

Artinya : “Dan jika kamu takut tidak akan dapat berlaku adil terhadap (hak-hak) perempuan yang yatim (bilamana kamu mengawaninya), maka kawinilah wanita-wanita (lain) yang kamu senangi dua, tiga, atau empat. Kemudian jika kamu takut tidak akan dapat berlaku adil, maka (kawinilah) seorang saja, atau budak-sudak yang kamu miliki, yang demikian itu adalah lebih dekat kepada tidak berbuat aniaya." (Departemen Agama Republik Indonesia, 1989).

Perintah untuk menikah pada ayat di atas merupakan tuntutan untuk melakukan pernikahan (thalabul fi li), namun tuntutan tersebut bersifat sunnah, bukan sebuah keharusan karena adanya kebolehan memilih antara kawin dan pemilikan budak, namun hukum asal sunnah ini dapat berubah menjadi wajib, haram maupun makruh. Jika seseorang tidak bisa menjaga kesucian diri dan 
akhlaknya kecuali dengan menikah, maka menikah menjadi wajib baginya, sebab menjaga kesucian dan akhlak hukumnya wajib bagi setiap muslim.

Tujuan perkawinan menurut agama Islam ialah untuk memenuhi petunjuk agama dalam rangka mendirikan keluarga yang harmonis, sejahtera dan bahagia. Harmonis dalam menggunakan hak dan kewajiban anggota keluarga, sejahtera artinya terciptanya ketenangan lahir dan batin, sehingga timbullah kebahagiaan, yakni kasih sayang antar anggota keluarga.

\section{Rukun Dan Syarat Sah Pernikahan}

Rukun yaitu sesuatu yang mesti ada yang menentukan sah dan tidaknya suatu pekerjaan (ibadah), dan sesuatu itu termasuk dalam rangkaian pekerjaan itu, seperti membasuh muka untuk wudhu dan takbiratul ihram untuk salat (Hakim, 1976), atau adanya calon pengantin laki-laki/perempuan dalam perkawinan.

Syarat yaitu sesuatu yang mesti ada yang menentukan sah dan tidaknya suatu pekerjaan (ibadah), tetapi sesuatu itu tidak termasuk dalam rangkaian pekerjaan itu, seperti menutup aurat untuk salat, atau calon pengantin laki-laki / perempuan itu harus beragama Islam (Al-Zuhaili, 1989). Sah yaitu sesuatu pekerjaan (ibadah) yang memenuhi rukun dan syarat (Al-Zuhaili, 1989).

\section{Rukun Pernikahan :}

Jumhur ulama sepakat bahwa rukun pernikahan itu terdiri atas :

1. Adanya calon suami dan istri yang akan melakukan perkawinan.

2. Adanya wali dari pihak calon pengantin wanita.

Akad nikah akan sah apabila ada seorang wali atau wakilnya yang akan menikahkannya, berdasarkan sabda Nabi Saw.

$$
\text { أيما امر أة نكحت بغير اذن وليها فنكاحها باطل (اخرجه الاربعة الا النسائ ) }
$$

Artinya : Perempuan mana saja yang menikah tanpa seizin walinya, maka pernikahannya batal. (Hadis riwayat empat perawi kecuali Nasa`i)

3. Adanya dua orang saksi.

Pelaksanaan akad nikah akan sah apabila dua orang saksi yang menyaksikan akad nikah tersebut, berdasarkan sabda Nabi Saw. :

$$
\text { لانكاح الا بولى وشاهدى عدل (رو اه احمد ). }
$$

Artinya : Tidak syah nikah tanpa ada wali dan dua orang saksi (diriwayatkan oleh Imam Ahmad)

4. Shighat akad nikah, yaitu ijab kabul yang diucapkan oleh wali atau wakilnya dari pihak wanita, dan dijawab oleh calon pengantin laki-laki. 


\section{Syarat sah pernikahan :}

Syarat-syarat perkawinan merupakan dasar bagi sahnya perkawinan. Apabila syarat-syaratnya terpenuhi, maka perkawinan itu sah dan menimbulkan adanya segala hak dan kewajiban sebagai suami istri.

1. Syarat-syarat Kedua Mempelai

a. Syarat pengantin pria

Syari'at Islam menentukan beberapa syarat yang harus dipenuhi oleh calon suami berdasarkan ijtihad para ulama, yaitu :

1) Calon suami beragama Islam

2) Terang (jelas) bahwa calon suami itu betul laki-laki

3) Orangnya diketahui dan tertentu.

4) Calon mempelai laki-laki itu jelas halal kawin dengan calon istri

5) Calon mempelai laki-laki tahu / kenal pada calon istri serta tahu betul calon istrinya halal baginya.

6) Calon suami rela (tidak dipaksa) untuk melakukan perkawinan itu

7) Tidak sedang melakukan ihram

8) Tidak mempunyai istri yang haram di madu dengan calon istri

9) Tidak sedang mempunyai istri empat (Daradjat, 1995).

b. Syarat pengantin perempuan :

1) Beragama Islam atau ahli Kitab

2) Terang bahwa ia wanita, bukan khunsa (banci)

3) Wanita itu tertentu orangnya

4) Halal bagi calon suami

5) Wanita itu tidak dalam ikatan perkawinan dan tidak masih dalam iddah

6) Tidak dipaksa / ikhtiyar

7) Tidak dalam keadaan ihram haji atau umrah (Daradjat, 1995).

2. Syarat-syarat Ijab Qabul

Perkawinan wajib dilakukan dengan ijab dan kabul dengan lisan. Inilah yang dinamakan akad nikah (ikatan atau perjanjian perkawinan). Bagi orang bisu sah perkawinannya dengan isyarat tangan atau kepala yang bisa dipahami.

Ijab dilakukan oleh pihak wali mempelai perempuan atau walinya, sedangkan kabul dilakukan oleh mempelai laki-laki atau wakilnya. 


\section{Syarat-syarat Wali}

Perkawinan dilangsungkan oleh wali pihak mempelai perempuan atau wakilnya dengan calon suami atau wakilnya.

Wali hendaklah seorang laki-laki, muslim, baligh, berakal dan adil (tidak fasik). Perkawinan tanpa wali tidak sah, berdasarkan sabda Nabi Saw. :

Artinya : Tidak sah pernikahan tanpa wali .

$$
\text { لانكاح الابولى ( رواه احمد ) . }
$$

$$
\begin{aligned}
& \text { ايماامر أة نكحت بغير اذن وليها فنكاحها باطل ( 3× ) فان دخل بها فلها المهر بما استحل }
\end{aligned}
$$

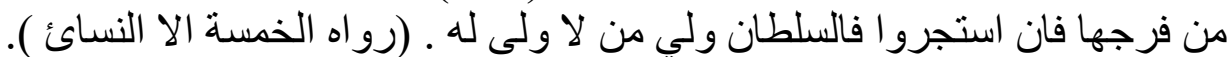

Artinya : Perempuan mana saja yang kawin tanpa izin walinya maka perkawinannya itu batal (3x). Apabila suami telah melakukan hubungan seksual maka si perempuan sudah berhak mendapatkan maskawin lantaran apa yang talah ia buat halal pada kemaluan perempuan itu. Apabila wali-wali itu enggan maka sultanlah (pemerintah) yang menjadi wali bagi orang yang tidak ada walinya.

4. Syarat-syarat Saksi

Saksi yang menghadiri akad nikah haruslah dua orang laki-laki, muslim, baligh, berakal, melihat dan mendengar serta mengerti (paham) akan maksud akad nikah (Ghazaly, 2006).

\section{PEMBAHASAN}

\section{Pernikahan Dini Menurut Hukum Islam}

Banyak faktor yang menyebabkan terjadinya pernikahan dini diantaranya disebabkan oleh pacaran yang berlebihan dan akhirnya hamil di luar nikah, atau karena tanggungan orang tua terlalu banyak sehingga anaknya yang masih di bawah umur terpaksa dikawinkan untuk mengurangi biaya orang tuanya karena adik-adiknya masih banyak, atau dikarenakan kehidupannya yang sangat susah sehingga seorang anak yang masih di bawah umur dinikahkan oleh orang tuanya, atau anak tersebut di kawinkan dengan orang yang jauh lebih tua umurnya namun kehidupannya sudah mapan sehingga diharapkan dengan perkawinan tersebut dapat membantu perekonomian keluarga bapak dan ibunya.

Adapun menikah dini, yaitu menikah pada usia remaja atau muda hukumnya sunnah atau mandub, demikian menurut Imam Taqiyuddin AnNabhani dengan berlandaskan pada hadis Nabi :

$$
\begin{aligned}
& \text { يا معشر الثباب من استطاع منكم الباءه فليتزوج فإنه أغض للبصر و أحصن للفرج ومن لم يستطع }
\end{aligned}
$$

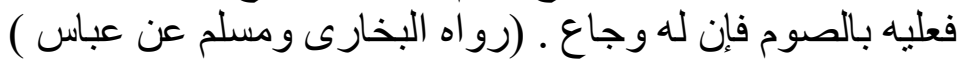

Artinya : "Wahai para pemuda, barang siapa yang telah mampu, hendaklah menikah, sebab dengan menikah itu akan lebih menundukkan pandangan dan 
akan lebih menjaga kehormatan. Kalau belum mampu, hendaklah berpuasa, sebab puasa akan menjadi perisai bagimu" (HR. Bukhari dan Muslim) (Mahalli \& Hasbullah, 2004).

Satu hal yang perlu digaris bawahi dari hadis di atas adalah perintah menikah bagi para pemuda dengan syarat jika ia telah mampu, maksudnya adalah siap untuk menikah. Kesiapan menikah dalam tinjauan hukum Islam meliputi 3 hal, yaitu :

1. Kesiapan fisik atau kesehatan khususnya bagi laki-laki, yaitu mampu menjalani tugasnya sebagai suami, tidak impoten. Khalifah Umar bin Khattab pernah memberi penangguhan selama satu tahun kepada seorang laki-laki (suami) yang impoten untuk berobat. Ini menunjukkan bahwa kesiapan "fisik" yang satu ini perlu mendapat perhatian serius.

2. Kesiapan harta atau materi; yang dimaksud dengan harta di sini ada dua macam yaitu harta sebagai mahar dan harta sebagai nafkah suami kepada istrinya untuk memenuhi kebutuhan pokok (al-hajat al-asasiyyah) bagi istri berupa sandang, pangan, dan papan yang wajib diberikan dalam kadar yang layak (bil ma`ruf).

3. Kesiapan Ilmu, yaitu kesiapan pemahaman hukum-hukum fikih yang ada hubungannya dengan masalah pernikahan, baik hukum sebelum menikah, seperti khitbah (melamar), pada saat menikah seperti syarat dan rukun akad nikah, maupun sesudah menikah seperti hukum menafkahi keluarga, thalak, rujuk. Syarat pertama ini didasarkan pada prinsip bahwa fardu àin hukumnya bagi seorang muslim untuk mengetahui hukum perbuatan sehari-hari yang dilakukannya atau yang akan dilakukannya.

Sekalipun dikatakan bahwa pernikahan dini hukum asalnya diperbolehkan menurut syariat Islam, tetapi tidak berarti ia dibolehkan secara mutlak bagi semua perempuan dalam semua keadaan. Sebab pada sebagian perempuan terdapat beberapa kondisi yang menunjukkan bahwa lebih baik ia tidak menikah pada usia dini. Terdapat beberapa ketentuan yang perlu diperhatikan dalam sebuah pernikahan dini agar tidak mengakibatkan efek negatif sebagaimana di lansir oleh banyak kalangan yang mayoritas berpandangan bahwa pernikahan dini selalu berkonotasi tidak baik.

1. Pada pernikahan perempuan yang masih sangat belia, lebih utama kalau dia dan calon suaminya tidak terpaut jauh usianya, kecuali untuk maksud yang dibenarkan. Imam An-Nasa i telah mengeluarkan sebuah riwayat di dalam Sunannya, demikian pula Ibnu Hibban di dalam Shahihnya, serta Al-Hakim di dalam Al-Mustadraknya, dan ia menilai shahih riwayat tersebut berdasarkan syarat Bukhari dan Muslim yang disepakati oleh Adz-Zahabi dari Buraidah, menyatakan bahwa Abu Bakar dan Umar melamar Fatimah, namun Rasulullah Saw. kemudian 
menikahkan Fatimah dengan Ali. Dari hadis tersebut dapat diambil kesimpulan bahwa usia calon suami perlu diperhatikan, yaitu sebaiknya tidak jauh dengan usia perempuan, karena kedekatan jarak usia ini diharapkan akan lebih dapat melahirkan keserasian diantara pasangan suami istri, dan lebih dapat melanggengkan pernikahan mereka.

2. Perempuan harus sudah siap secara fisik, karena banyak perempuan yang sudah baligh namun belum siap untuk menikah karena kondisi tubuhnya yang lemah atau penyakit yang membuatnya tidak memiliki fisik yang prima sehingga tidak mampu menjalankan tugasnya sebagai istri.

3. Perempuan tersebut sudah matang secara mental dan terdidik untuk dapat memenuhi tanggung jawab. Ini bukan berarti ia harus mengetahui seluk beluk kehidupan berumah tangga secara sempurna, ketika berinteraksi dengan suami, mengasuh anak, dan lain sebagainya. Kedua poin tersebut pantas mendapat perhatian lebih berdasar hadis Nabi bahwa beliau tidak menyuruh menikah kepada seluruh pemuda tanpa terkecuali bagi mereka yang dianggap mempunyai al-ba'ah, yaitu kemampuan memberi nafkah.

Begitu banyak pelajaran yang bisa kita eksplorasi dari hikmah disyariatkannya suatu hukum baik itu mubah, sunnah, wajib, makruh, maupun haram. Jika kita cermati lebih detail bahwa ternyata pernikahan dini berdampak positif bagi kemaslahatan jika dilakukan dengan tanpa adanya unsur keterpaksaan baik karena kemauan orang tua maupun terpaksa menikah karena sudah telanjur hamil.

Usia pernikahan yang ideal bagi perempuan adalah 21-25 tahun, sedangkan bagi laki-laki adalah 25-28 tahun. Karena pada usia tersebut organ reproduksi pada perempuan sudah berkembang dengan baik dan kuat, serta secara psikologis sudah dianggap matang untuk menjadi calon orang tua bagi anak-anaknya. Sementara kondisi fisik dan psikis laki-laki pada usia tersebut juga sudah kuat sehingga mampu menopang kehidupan keluarga dan melindunginya baik secara psikis, emosional, ekonomi dan sosial (Rumulyo, 1999).

Pernikahan dini berdampak pada kesehatan reproduksi anak perempuan. Anak perempuan berusia 10-14 tahun memiliki kemungkinan meninggal lima kali lebih besar dibanding perempuan yang berusia antara 2025 tahun, sementara anak yang berusia 15-19 tahun kemungkinannya dua kali lebih besar. Prof.Dr. dr. Dadang Hawari, seorang psikiater menyatakan bahwa secara Psikologis dan biologis, seseorang matang berproduksi dan bertanggung jawab sebagai ibu rumah tangga antara usia 20-25 tahun bagi perempuan atau 25 sampai 30 tahun bagi laki-laki. Sebelum usia tersebut dianggap terlalu cepat yang disebutnya dengan istilah pre-cocks yaitu matang sebelum waktunya. 
Di Indonesia undang-undang yang mengatur tentang pernikahan tertuang dalam Undang-Undang No.1 Tahun 1974 yang menyatakan bahwa pernikahan adalah ikatan lahir batin antara seorang pria dengan seorang wanita sebagai seorang suami istri dengan tujuan membentuk keluarga yang bahagia dan kekal berdasarkan Ketuhanan Yang Maha Esa. Adapun batas usia pernikahan dalam Undang-Undang Perkawinan bab II pasal 7 ayat 1 disebutkan bahwa pernikahan hanya diizinkan jika pihak pria mencapai umur 19 tahun dan pihak perempuan sudah mencapai umur 16 tahun. Kebijakan pemerintah dalam menetapkan batasan usia minimal pernikahan ini tentunya sudah melalui proses dan berbagai pertimbangan. Hal ini dimaksudkan agar kedua belah pihak benar-benar siap dan matang dari aspek fisik, psikis dan mental.

Lebih lanjut dijelaskan dalam pasal 6 ayat 2 Undang-Undang No 1 Tahun 1974 bahwa untuk melangsungkan pernikahan seseorang yang belum mencapai usia 21 tahun harus mendapat izin dari kedua orang tuanya. Namun dalam prakteknya di masyarakat secara umum masih banyak yang melangsungkan pernikahan di usia muda atau di bawah umur.

Secara umum, sebagian masyarakat yang melangsungkan pernikahan pada usia muda dipengaruhi oleh beberapa faktor, yaitu :

1) Pernikahan dini terjadi karena keadaan ekonomi keluarga yang berada di bawah garis kemiskinan, sehingga dengan menikahkan salah satu anak perempuannya sekalipun masih sangat belia, akan cukup meringankan beban orang tuanya khususnya dari sisi ekonomi.

2) Orang tua, anak dan masyarakat dengan tingkat kesadaran pendidikan yang rendah.

3) Ada kekhawatiran dikalangan orang tua akan mendapatkan aib karena anak perempuannya sudah berpacaran dengan laki-laki akan segera menikahkannya.

4) Gencarnya media massa baik cetak maupun elektronik khususnya internet yang belum bisa dikendalikan dalam batas aman untuk dikonsumsi publik yang mengekspos pornografi dan adegan-adegan yang tidak layak dipertontonkan secara umum menyebabkan remaja modern kian banyak yang terjerembab dalam lingkup "permissive society" yang memperbolehkan pola hidup yang bagaimanapun yang mereka inginkan.

5) Perkawinan usia muda terjadi karena orang tua takut anaknya menjadi perawan tua jika tidak segera menerima pinangan dari laki-laki yang melamarnya (Ghazaly, 2006).

\section{Pendidikan Anak}

Pendidikan dari segi bahasa berasal dari kata dasar didik, dan diberi awalan men, menjadi mendidik, yaitu kata kerja yang artinya memelihara dan 
memberi latihan (ajaran). Pendidikan sebagai kata benda berarti proses perubahan sikap dan tingkah laku seseorang atau kelompok orang dalam usaha mendewasakan manusia melalui upaya pengajaran dan latihan (Poerwadarminta, 1985).

Ada satu hal penting yang bisa ditarik dari definisi di atas yang tercakup dalam proses pendidikan yaitu pendewasaan diri melalui pengajaran dan latihan.

Dilihat dari cakupannya, pendidikan dapat dipahami pada tiga wilayah pengertian. Pertama, pendidikan dalam makna maha luas, yakni ketika pendidikan diproporsikan sebagai kenyataan kehidupan manusia. Kehidupan adalah pendidikan dan pendidikan adalah kehidupan itu sendiri. Kedua, pendidikan dalam makna luas terbatas, ketika pendidikan diproporsikan sebagai sejumlah program pengembangan kualitas manusia. Ketiga, pendidikan dalam makna sempit, yakni ketika pendidikan diproporsikan terbatas pada formal sekolah.

Undang-Undang No. 23 Tahun 2002 tentang Perlindungan Anak (Pasal 26 ayat 1) menyatakan bahwa Orang tua berkewajiban dan bertanggung jawab untuk mengasuh, memelihara, mendidik dan melindungi anak.

Anak sebagai keturunan bukan saja menjadi buah hati, tetapi juga sebagai penolong dalam hidup di dunia, bahkan akan memberi tambahan amal kebajikan di akhirat nanti, manakala dapat mendidiknya menjadi anak yang saleh, sebagaimana sabda Nabi Saw. yang diriwayatkan oleh Muslim dari Abu Hurairah :

$$
\begin{aligned}
& \text { إذا مات الإنسان انقطع عمله الا من ثناث : صدقة جارية أو علم ينتفع به او ولد صالح يدعوله }
\end{aligned}
$$

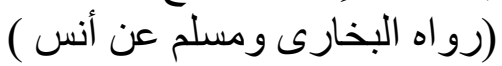

Artinya : Apabila manusia meninggal dunia maka putuslah amalnya kecuali tiga hal : Shadaqah jariyah, atau ilmu yang bermanfaat, atau anak yang shaleh yang selalu mendoakannya. (HR. Bukhari dan Muslim dari Anas).

Lembaga pendidikan keluarga menempatkan ibu dan bapak sebagai pendidik kodrati, hubungan kekeluargaan yang intim dan didasari oleh kasih sayang serta perasaan tulus ikhlas merupakan faktor utama bagi para orang tua dalam membimbing anak-anak. Tanggung jawab pendidikan yang perlu disadarkan dan dibina oleh kedua orang tua terhadap anaknya, antara lain adalah sebagai berikut:

1. Memelihara dan membesarkannya. Tanggung jawab ini merupakan dorongan alami untuk dilaksanakan karena anak memerlukan makan, minum, dan perawatan agar ia dapat hidup secara berkelanjutan. 
2. Melindungi dan menjamin kesehatannya, baik secara jasmaniah maupun rohaniah dari berbagai gangguan penyakit atau bahaya lingkungan yang dapat membahayakan dirinya.

3. Mendidiknya dengan berbagai ilmu pengetahuan dan keterampilan yang berguna bagi kehidupannya kelak sehingga saat dewasa, mereka mampu berdiri sendiri dan membantu orang lain.

4. Membahagiakan anak untuk dunia dan akhirat dengan memberinya pendidikan agama sesuai dengan ketentuan Allah sebagai tujuan hidup muslim (Arifin, 1991).

Hadari Nawawi menjelaskan tugas pokok pendidikan di keluarga sebagai berikut :

1. Membantu anak-anak memahami posisi dan peranannya masing-masing sesuai dengan jenis kelaminnya, agar mampu saling menghormati dan saling menolong dalam melaksanakan perbuatan baik yang diridhai Allah Swt.

2. Membantu anak mengenal dan memahami nilai-nilai atau norma-norma yang mengatur kehidupan berkeluarga, bertetangga, bermasyarakat dan mampu melaksanakannya untuk memperoleh ridha Allah Swt.

3. Mendorong anak untuk mencari ilmu dunia dan ilmu agama agar mampu merealisasikan dirinya (self realization) sebagai suatu diri individu dan sebagai anggota masyarakat yang beriman.

4. Membantu anak-anak memasuki kehidupan bermasyarakat setahap demi setahap melepaskan diri dari ketergantungan pada orang tua dan orang dewasa lainnya, serta mampu bertanggung jawab.

5. Membantu dan memberi kesempatan serta mendorong anak-anak mengerjakan sendiri dan berpartisipasi dalam melaksanakan kegiatan keagamaan, untuk memperoleh pengalaman sendiri secara langsung (Nawawi, 1993).

Di lingkungan keluarga, orang tua dan orang dewasa lainnya perlu membantu anak dalam menghayati dan mengamalkan ajaran Islam, setahap demi setahap sesuai dengan masa perkembangan anak-anak. Oleh karena itu, pendidikan keluarga menjadi penting.

Seorang anak adalah amanat bagi kedua orang tuanya, kalbunya yang masih suci bagaikan permata yang begitu polos, bebas dari segala macam pahatan dan gambaran, siap untuk menerima setiap pahatan apapun, selalu cenderung pada kebiasaan yang diberikan kepadanya. Jika dia dibiasakan untuk melakukan kebaikan, niscaya dia akan tumbuh menjadi orang yang baik, sehingga memperoleh kebahagiaan dunia dan akhirat, semua itu ditentukan oleh orang tuanya sebagai pendidik, sebaliknya bila anak dibiasakan melakukan hal-hal yang buruk dan ditelantarkan tanpa memperoleh pendidikan dan 
pengajaran seperti hewan ternak yang dilepaskan, bebas semaunya begitu saja, maka anak akan menjadi celaka dan binasa (Abdurrahman, 2005).

Dalam konteks ini, perkembangan anak menuju kematangannya memerlukan bimbingan para pendidik, baik orang tua maupun guru. Dengan demikian, para pendidik bertanggung jawab penuh terhadap perkembangan optimal anak, sejak usia dini dengan memberikan pendidikan, dan bimbingan yang memenuhi seluruh aspek pertumbuhan dan perkembangan anak sehingga anak pada usia dini benar-benar siap untuk menerima pendidikan pada usia selanjutnya di sekolah formal.

\section{Dampak Pernikahan Dini Bagi Pendidikan Anak}

Pernikahan dini adalah pernikahan yang dilakukan oleh seorang laki-laki dan seorang perempuan di bawah usia yang seharusnya belum siap untuk melaksanakan pernikahan. Banyak faktor yang menyebabkan terjadinya pernikahan dini diantaranya disebabkan oleh pacaran yang berlebihan dan akhirnya hamil di luar nikah, atau karena tanggungan orang tuanya terlalu banyak sehingga anaknya yang masih di bawah umur terpaksa dikawinkan untuk mengurangi biaya orang tuanya karena adik-adiknya masih banyak, atau dikarenakan kehidupannya yang sangat susah sehingga seorang anak yang masih di bawah umur dinikahkan oleh orang tuanya, atau anak tersebut di kawinkan dengan orang yang jauh lebih tua umurnya namun kehidupannya sudah mapan sehingga diharapkan dengan perkawinan tersebut dapat membantu perekonomian keluarga bapak dan ibunya.

Saat pasangan pernikahan dini tersebut mempunyai anak, pasangan tersebut belum bisa mengurus anaknya, kedua pasangan tersebut lebih mementingkan ego masing-masing seperti si ibu asyik dengan sendirinya bermain dengan teman-temanya dan kurang memperhatikan anaknya dan si laki-laki juga lebih mementingkan main dari pada di rumah, si laki-laki jarang di rumah dan mengurus anak dan istrinya sehingga anaknya lebih dominan di urus oleh neneknya atau asisten rumah tangga, dan terkadang si ibu asyik dengan handphone nya demikian juga dengan si ayah yang asyik dengan handphone nya juga sehingga urusan rumah tangga dan pendidikan anak terbengkalai di sebabkan usia mereka yang masih muda yang seharusnya mereka itu memang masih usia bemain dan sekolah namun mereka sudah berumah tangga yang dituntut untuk melaksanakan kewajiban masing-masing, yang berhubungan dengan tanggung jawab sebagai seorang suami dan istri atau sebagai ibu dan bapak dari anak-anaknya yang memang sangat membutuhkan perhatian dan pendidikan dari orang tuanya.

masyarakat memandang pernikahan muda merupakan pernikahan yang belum menunjukkan adanya kematangan dan kedewasaan dan secara ekonomi masih labil. Seiring berkembangnya zaman, image yang berkembang di 
masyarakat justru sebaliknya, Arus globalisasi yang melesat sangat cepat banyak merubah paradigma berpikir masyarakat secara luas. Pernikahan di usia yang sangat belia dianggap sebagai sesuatu yang tabu, karena dipandang sebagai banyak membawa efek negatif khususnya bagi pihak perempuan, sekalipun demikian fenomena pernikahan dini masih banyak dijumpai terutama di daerah-daerah yang mayoritas tingkat kesadaran pendidikannya masih relatif rendah.

Pernikahan dini sangat berdampak bagi pendidikan anak yang masih memerlukan bimbingan dari orang tua terutama orang tua yang kurang dalam memberikan kasih sayang terhadap anak, selain itu ekonomi orang tua yang kurang memadai dapat mengganggu pendidikan anak disekolah, kurang harmonisnya keluarga dapat menggangggu mental anak, karena orang tua yang menikah dini masih memikirkan diri mereka sendiri, pernikahan dini dapat berdampak positif dan negatif.

Dampak positif selama pernikahan dini diawali dengan niat yang baik untuk mengharap ridho Allah maka pernikahan dini itu akan membawa dampak yang positif seperti seorang remaja putri akan lebih muncul sifat keibuannya setelah ia menikah dan punya anak begitu juga seorang remaja putra akan lebih bertanggung jawab dan memiliki pengalaman langsung dalam rumah tangga dan membina rumah tangganya, menghindarkan diri dari perbuatan zina, pergaulan bebas dan sebagainya.

Dampak negatif jika pada awalnya niat menikah negatif seperti halnya menutupi aib keluarganya maka akan menimbulkan hal yang negatif pula seperti KDRT (kekerasan dalam rumah tangga) yang biasa dilakukan oleh suami terhadap istrinya, pendidkan anak-anak terbengkalai karena ketidak siapan orang tua dalam mengurus anak-anaknya, kesulitan ekonomi dan kondisi keluarga yang kurang harmonis. Beberapa dampak positif yang ditimbulkan dari pernikahan dini adalah :

1. Kemandirian sepasang suami istri untuk memikul tanggung jawabnya sendiri tanpa menjadi tanggungan orang lain.

2. Apabila jarak usia orang tua dan anak berdekatan, maka ketika anaknya membutuhkan perhatian dalam hal biaya pendidikan, diharapkan orang tuanya masih sehat wal afiat untuk menunaikan kewajiban tersebut. ${ }^{1}$

3. Memiliki tingkat kemungkinan hamil yang tinggi. Kehamilan bagi perempuan yang menikah pada usia muda akan lebih tinggi kemungkinannya dibandingkan dengan pernikahan yang dilakukan di usia yang sangat matang.

\footnotetext{
1 Alexis Carell, Man, The Unknown, mengatakan bahwa semakin dekat jarak waktu yang memisahkan antara dua generasi, semakin kuat pula pengaruh moral orang tua kepada anaknya. hal. 215.
} 
4. Meminimalisir terjadinya perbuatan asusila dan perilaku menyimpang dikalangan muda-mudi.

5. Meringankan beban para orang tua yang terlalu fakir, dan menyalurkan hasrat sang suami secara syar`i.

6. Saat belum menikah, anak-anak muda senantiasa dihinggapi lintasanlintasan pikiran yang mengganggu. Pelampiasan nafsu akan menjadi tujuan yang paling penting, terutama saat mereka asyik berpacaran dengan lawan jenisnya. Karena itu untuk menghindari dampak negatif, maka keputusan untuk melakukan pernikahan dini dapat dibenarkan.

7. Meningkatkan jumlah populasi umat Islam. Karena rentang masa produktifnya yang sedemikian panjang memungkinkan menghasilkan keturunan yang jauh lebih banyak. Diharapkan bukan hanya jumlah populasi secara kuantitas yang semakin banyak tetapi populasi calon penerus generasi yang banyak secara kuantitas dan tinggi secara kualitas.

Selain dampak positif pernikahan dini yang diuraikan di atas berikut ini akan dipaparkan pula efek negatif menunda-nunda pernikahan, diantaranya :

1. Mengakibatkan keengganan atau lemahnya semangat para pemuda untuk menikah sehingga fenomena hidup melajang menjadi salah satu pilihan atau gaya hidup karena sudah merasa mampu memenuhi kebutuhannya sendiri tanpa perlu ada orang yang mendampingi hidupnya sebagai pasangan hidup.

2. Kehamilan di luar rahim bagi wanita berusia sangat matang kemungkinannya lebih besar daripada wanita yang berusia antara 15-24 tahun.

3. Ilmuan Amerika mengatakan bahwa perbandingan jumlah kasus aborsi pada wanita di atas usia 35 tahun lebih banyak 3 sampai 4 kali dibandingkan dengan wanita yang hamil di bawah usia tersebut.

4. Wanita hamil beresiko tinggi bagi mereka yang kehamilan pertama dialami pada usia lanjut yang terus menunda pernikahan sehingga akan membahayakan baik bagi ibu hamil maupun bagi bayi yang dikandungnya.

5. Operasi caesar, kelahiran prematur, cacat fisik, kematian janin di dalam rahim sebelum lahir, akan lebih besar kemungkinannya ketika usia ibu hamil semakin banyak bertambah.

6. Semakin mundur usia nikah akan semakin menurun semangat orang untuk menikah dan ini banyak terjadi di negara-negara barat, sehingga banyak perempuan yang melahirkan anak tanpa proses pernikahan. Mereka lebih memilih hamil dengan cara inseminasi buatan dengan sel sperma yang mereka bisa dapatkan di bank-bank sperma.

7. Kanker payudara dan rahim lebih kecil prosentasenya bagi wanita yang pernah hamil di usia muda dari pada mereka yang hamil pada usia yang sangat matang. 
Setiap orang mencita-citakan untuk membangun rumah tangga yang bahagia, harmonis, tenteram, sakinah. Rumah tangga yang diliputi oleh iklim saling mencintai (mawaddah) dan saling mengasihi (rahmah). Rumah tangga yang demikian bukan saja menciptakan suasana yang mesra di kalangan keluarga, tetapi juga memancarkan kemesraan itu kepada orang lain, terutama kepada tetangga dan lingkungan.

Rumah tangga merupakan komponen terkecil dalam suatu struktur masyarakat. Rumah tangga sebagai wadah pendidikan anggota-anggotanya ini membentuk masyarakat yang sehat, kuat dan bermoral tinggi. Untuk mencapai tujuan tersebut diperlukan peraturan sebagai pedoman hidup bagi segenap anggota keluarga dalam pelaksanaan tugas/ kewajiban dan hak mereka masingmasing.

Anak merupakan amanah yang diberikan Allah kepada kita sebagai orang tua. Amanah tersebut akan dipertanggungjawabkan di hari kemudian nanti. Oleh karena itu, bimbingan serta arahan dari orang tua sangat penting dalam kehidupan seorang anak hingga mereka mandiri. Dalam ajaran agama sangat jelas perintah dan tanggung jawab orang tua dalam mendidik anak hingga si buah hati yang dilahirkan memiliki etika terpuji. Bahkan, perencanaan dalam pengasuhan seorang anak telah ditentukan sejak masa dalam kandungan. Umum diketahui, bahwa bayi dalam kandungan ibunya telah dimungkinkan untuk dibina, yaitu dengan memperdengarkan ayat-ayat suci serta tingkah laku ibu yang terpuji.

Orang tua bertanggung jawab di hadapan Allah Swt. tentang pendidikan dan pembinaan anak-anaknya. Bila orang tua telah mengemban tanggung jawab itu dengan baik, semua akan berbahagia di dunia dan di akhirat. Sebaliknya, bila orang tua mengesampingkannya, anak akan menghadapi kondisi buruk dan orang tuanya akan menanggung beban dosa atas kelalaiannya itu. Salah satu aspek penting dalam perkembangan anak, adalah pembinaan moral mereka. Pembinaan akhlak anak-anak mesti dilakukan sejak dini supaya kecenderungannya dalam menyukai kebaikan tetap terjaga. Dengan itu, anak-anak akan menjadi insan-insan terpuji nantinya, dan sumber kebahagiaan dan ketenangan orang tua mereka serta mendatangkan kebaikan bagi mereka, di dunia dan di akhirat. Jadi, mendidik anak termasuk amalan shaleh yang dapat digunakan oleh orang tua untuk mendekatkan diri kepada Allah Swt. dan menjadi sedekah jariyah yang pahalanya akan mengalir terus-menerus.

Peranan seorang ibu di dalam rumah tangga adalah sangat penting bagi kebahagiaan suaminya dan bagi perkembangan jasmani dan rohani anakanaknya. Ketentraman dan pembinaan kasih sayang di dalam rumah tangga itu merupakan kewajiban seorang ibu.

Ada 3 (tiga) aktifitas ibu di dalam rumah tangga, yaitu : 
a) Aktifitas sebagai seorang istri pendamping, pengayom dan pengatur rumah tangga suami.

b) Aktifitas sebagai seorang ibu, berfungsi reproduksi dan bertanggung jawab dalam pendidikan hasil reproduksinya.

c) Aktifitas sebagai pencipta suasana keagamaan di dalam keluarga / rumah tangganya.

Kebahagiaan senantiasa merupakan dambaan setiap pribadi maupun keluarga, untuk memperoleh kebahagiaan dilakukan berbagai macam usaha dan doa. Ada yang hanya mengharapkan kebahagiaan dunia dan tentu saja bagi ummat Islam kebahagiaan yang diharapkan adalah kebahagiaan dunia dan akhirat. Untuk memperoleh kebahagiaan di dunia dan akhirat perlu adanya usaha yang seimbang antara kepentingan dunia dengan kepentingan di akhirat.

Dalam syari`at Islam sudah diajarkan bahwa mendidik dan membimbing anak merupakan suatu kewajiban bagi seorang muslim karena anak merupakan amanat yang harus dipertanggungjawabkan oleh orang tua. Pernyataan tersebut berangkat dari hadis Rasulullah Saw. yang berbunyi :

$$
\text { كل مولود يولد على الفطرة , فأبو اه أن يهودانه أو ينصر انه أو يمجسانه. }
$$

Artinya : "Sesungguhnya setiap anak itu dilahirkan dalam keadaan fitrah (suci), orang tuanya lah yang akan menjadikan anak tersebut Yahudi, Nasrani, atau pun Majusi."

Hadis tersebut mengandung makna bahwa sesungguhnya kesuksesan atau bahkan masa depan anak adalah tergantung bagaimana orang tua mendidik dan membimbingnya. Hadis tersebut juga bermakna bahwa setiap anak yang lahir sesungguhnya sudah memiliki potensi, namun potensi itulah yang kemudian bisa menghasilkan sesuatu yang maksimal, jika diasah oleh lingkungan (keluarga dan sekitar) dengan baik. Hal ini juga dipertegas lagi dalam firman Allah Swt :

$$
\begin{aligned}
& \text { ياأيها الذين ءامنو ا قو آ أنفسكم وأهليكم نار اوقودها الناس و الحجارة عليها ملآئكة غلاظ شداد }
\end{aligned}
$$

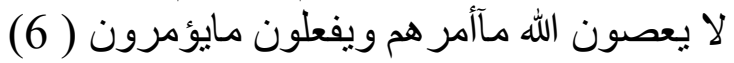

Artinya : "Hai orang-orang yang beriman, peliharalah dirimu dan keluargamu dari api neraka yang bahan bakarnya adalah manusia dan batu, penjaganya malaikat-malaikat yang kasar, keras, dan tidak mendurhakai Allah terhadap apa yang diperintahkan-Nya kepada mereka dan selalu mengerjakan apa yang diperintahkan." (Q.S. At-Tahrim 66 :6) (Departemen Agama Republik Indonesia, 1989).

Maksud dari ayat tersebut adalah perintah memelihara keluarga, termasuk anak, bagaimana orang tua bisa mengarahkan, mendidik, dan mengajarkan anak agar dapat terhindar dari siksa api neraka. Hal ini juga 
memberikan arahan bagaimana cara orang tua harus mampu menerapkan pendidikan yang bisa membuat anak mempunyai prinsip untuk menjalankan hidupnya dengan positif, menjalankan ajaran Islam dengan benar, sehingga mampu membentuk mereka menjadi anak yang mempunyai akhlakul karimah, dan menunjukkan kepada mereka hal-hal yang bermanfaat (Daulay, 2015).

Dari keluarga yang kuat beragama, akan muncul anak yang saleh, di dalam pekerjaan mendidik anak, orang tua melakukannya dengan tekad yang bulat dan niat yang suci guna menghasilkan anak yang baik dan saleh, maka diharapkan pertumbuhan lahirnya anak yang baik. Mengharapkan putra putri terbaik hanyalah dapat tercapai jikalau rumah tangga berjalan secara harmonis. Jika orang tua hidup rukun dan damai, dan suasana rumah tangga yang diliputi oleh rasa kasih sayang, barulah akan muncul anak-anak baik yang terlatih akidahnya.

Ajaran Islam memberikan tuntunan yang sempurna bagi umat manusia dalam keluarga / rumah tangga. Dalam hal ini Dr. Zakiyah Daradjat menguraikan sebagai berikut : Dalam ajaran Islam masalah keluarga termasuk masalah yang banyak mendapat perhatian. Mulai dari memilih jodoh, ditentukan siapa yang boleh menjadi suami atau istri, kemudian prosedur pernikahan, selanjutnya kewajiban hak kedua belah pihak, apa yang wajib dipenuhi terhadap yang lainnya dan apa pula yang harus dihindari. Bahkan hubungan antara satu sama lain, mulai dari hubungan yang paling asasi sampai kepada hubungan yang nampaknya sangat sederhana dan ringan dalam kehidupan sehari-hari, diberikan petunjuknya jika terjadi ketidak serasian, percekcokan dan pertengkaran, diatur pula bagaimana cara menyelesaikannya, bahkan diatur pula hubungan dengan orang tua (Daradjat, 1988).

Landasan dan tujuan sebuah keluarga, dilukiskan oleh Allah Swt. dalam Alquran surah ar-Ruum ayat 21 :

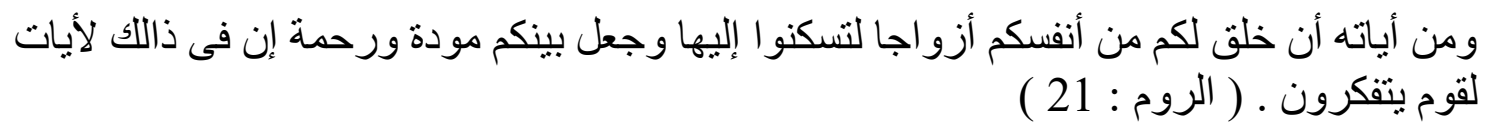

Artinya : Dan di antara tanda-tanda kekuasaan-Nya ialah Dia menciptakan untukmu istri-istri dari jenismu sendiri, supaya kamu cenderung dan merasa tenteram kepadanya, dan dijadikan-Nya diantaramu rasa kasih dan sayang. Sesungguhnya pada yang demikian itu benar-benar terdapat tanda-tanda bagi kaum yang berfikir." (QS. Ar-Ruum : 21) (Departemen Agama Republik Indonesia, 1989).

Adapun faktor-faktor yang lebih banyak mempengaruhi dalam menciptakan rumah tangga bahagia dapat disimpulkan dalam enam faktor, yaitu : 
1. Suami istri mempunyai niat yang ikhlas dalam membangun rumah tangganya.

2. Setiap anggota rumah tangga atau keluarga memahami dan dapat menjalankan fungsinya masing-masing.

3. Terciptanya suasana keagamaan dalam kehidupan rumah tangga seharihari.

4. Terpeliharanya kesehatan hidup.

5. Terpenuhinya kebutuhan ekonomi rumah tangga.

6. Tercapainya fungsi pendidikan keluarga terutama bagi anak-anak (Noor, 1983).

\section{KESIMPULAN}

Sekalipun dikatakan bahwa pernikahan dini hukum asalnya diperbolehkan menurut syariat Islam, tetapi tidak berarti ia dibolehkan secara mutlak bagi semua perempuan dalam semua keadaan. Sebab pada sebagian perempuan terdapat beberapa kondisi yang menunjukkan bahwa lebih baik ia tidak menikah pada usia dini.

Anak merupakan amanah yang diberikan oleh Allah Swt. kepada para orang tua, sehingga sudah sepatutnyalah jika amanah tersebut selalu dijaga dengan sebaik-baiknya, salah satu caranya adalah mendidik mereka dengan benar, khususnya masalah pendidikan agama seperti mengajarkan mereka untuk melaksanakan shalat. Begitu besar dan pentingnya peranan orang tua dalam mendidik anak-anaknya sejak usia dini, bahkan sejak anak masih dalam kandungan, apabila semua berjalan dengan baik maka akan membentuk anak menjadi pribadi yang baik, antara lain anak akan taat menjalankan perintah Allah Swt. dan akan menjadi bekal yang baik bagi kehidupan mereka di masa yang akan datang.

\section{DAFTAR PUSTAKA}

Abdurrahman, J. (2005). Tahapan Mendidik Anak: Teladan Rasulullah. Jakarta: IBIS. al-Jurjaniy, as-S. A. bin M. (1988). Kitab al-Ta`rifat (3rd ed.). Beirut: Dar al-Kutub al-Ilmiyah.

Al-Kahlaniy, M. bin I. (n.d.). Subul as-Salam (3rd ed.). Bandung: Dahlan.

Al-Zuhaili, W. (1989). al-Fiqh al-Islami wa Adillatuh (3rd ed.). Beirut: Dar al-Fikr.

Arifin, M. (1991). Materi Pokok Dasar-dasar Kependidikan. Jakarta: Dirjen Binbaga Islam \& Universitas Terbuka.

As-Syathibi, I. (n.d.). Al-Muwafaqat. Beirut: Darul Kutub Ilmiah.

Daradjat, Z. (1988). Kebahagiaan. Jakarta: YPI.

Daradjat, Z. (1995). Ilmu Fiqh. Yogyakarta: Dana Bhakti Wakaf. 
Daulay, N. (2015). Psikologi Kecerdasan Anak. Medan: Perdana Publishing.

Departemen Agama Republik Indonesia. (1989). Alquran dan Terjemahnya. Bandung: Gema Risalah Press.

Depdikbud. (1994). Kamus Besar Bahasa Indonesia (3rd ed.). Jakarta: Balai Pustaka.

Ghazaly, A. R. (2006). Figh Munakahat. Jakarta: Kencana Prenada Media Group.

Hakim, A. H. (1976). Mabadi Awwaliyyah. Jakarta: Bulan Bintang.

Mahalli, A. M., \& Hasbullah, A. R. (2004). Hadis-Hadis Muttafaq `Alaih, Bagian Munakahat \& Muamalat. Jakarta: Kencana.

Nawawi, H. (1993). Pendidikan dalam Islam. Surabaya: Al-Ikhlas.

Noor, F. M. (1983). Menuju Keluarga Sejahtera dan Bahagia. Bandung: Al-Ma`arif.

Poerwadarminta, W. J. S. (1985). Kamus Besar Bahasa Indonesia. Jakarta: Balai Pustaka.

Rumulyo, I. (1999). Hukum Perkawinan Islam. Jakarta: Bumi Aksara. 